\title{
Relationship Of Work Status And Mother Education Level And Cadre Support With Mother's Visitations To Posyandu
}

\author{
Mahyuni *, Erida Wydiamala **, Lenie Marlinae ***, \\ Husaini ****, Syamsul Arifin ***** \\ DOI: 10.29322/IJSRP.11.01.2021.p10981 \\ http://dx.doi.org/10.29322/IJSRP.11.01.2021.p10981
}

\begin{abstract}
Background:Posyandu is one of the Community Based Health Efforts (UKBM) which is managed and organized from, by, for and with the community to empower and provide facilities for the community to obtain basic health services for mothers, babies and toddlers. The achievement of visits and weighing of children under five shows the indicator is below the national target with the standard set by the government of $85 \%$. Many factors are related to and influence the use and visit of mothers under five to posyandu. Many previous research studies have examined the factors associated with maternal visits to posyandu.
\end{abstract}

Purpose: This study aims to estimate the tendency of the relationship between work status and mother's education level as well as cadre support with maternal visits to the posyandu.

Method:This study used a meta-analysis method with research tracing with cross sectional design on the Google Scholar database and Garuda Portal. The results of identification and after going through the selection stage on relevant studies according to the criteria were reviewed as many as 7 articles. Pooled Odds Ratio (pOR) is calculated using the fixed-effect and random effect models according to the heterogeneity test using Review Manager 5.3.

Result: Maternal employment status (5 articles), mother's education level (4 articles) and cadre support ( 3 articles) were significantly associated with maternal visits to posyandu with $\mathrm{POR}=5.74(95 \% \mathrm{CI}=2.16-15.26)$ for employment status, $\mathrm{POR}=10.71(95 \% \mathrm{CI}=1.63-70.61)$ for education level and $\mathrm{POR}=29.40(95 \% \mathrm{CI}=8.19-105.63)$ for cadre support.

Conclusion: Mother's employment status has a moderate level of relationship with maternal visits to posyandu, while the level of maternal education and cadre support has a strong relationship with maternal visits to posyandu.

Keywords: Mother's employment status, mother's education level, cadre support, posyandu visits

\section{INTODUCTION}

Health development is an integral part of national development in realizing an optimal public health degree. The

This publication is licensed under Creative Commons Attribution CC BY.

http://dx.doi.org/10.29322/IJSRP.11.01.2021.p10981
National Mid-Term Development Plan (RPJMN) 2020-2024 in the health sector, which refers to the Health Development Indicators targeted for up to 2024, including improving the health status of mothers and children, increasing the nutritional status of the community and increasing control of infectious diseases and risk factors for non-communicable diseases, increasing health system performance and increased equitable access to quality health services, as well as increased social protection for all residents.

The form of promotive and preventive efforts in community empowerment in the health sector is to develop Community-Based Health Efforts (UKBM), one of which is through the posyandu program. Posyandu is one of the Community-Based Health Efforts that are managed and organized from, by, for and with the community to empower and provide facilities for the community to obtain basic health services for mothers, babies and toddlers. The success of the posyandu is illustrated by the coverage of the SKDN, namely: (1). S: All toddlers in the Posyandu working area. (2). K: All toddlers who have KMS. (3). D: The weighed toddler. (4). N: Toddlers who gain weight (Ministry of Health, 2015).

In the report on the target of weighing and visiting toddlers on a national scale in Indonesia in 2016 the percentage of coverage at posyandu (D / S) was 73\%, in 2017 it was $81.8 \%$ and in 2018 it was $80.7 \%$, while the target set was $85 \%$. . This shows that the coverage for under-five weighing is not achieved. The highest percentage was in Bali Province at $84.71 \%$, while the lowest percentage was in Central Kalimantan at $32.51 \%$. (Indonesian Ministry of Health, 2019).

A large number of studies have been conducted to analyze the factors associated with maternal visits to posyandu including maternal age, toddler age, child gender, education, occupation, family income, parity, family support, support from officers, support from cadres, support from figures. community, facilities, access and distance.

Meta-analysis research has a role in scientific research. This can be seen through drawing more valid and reliable conclusions by increasing the sample size because it is done by reviewing several studies with the same subject so that the resulting level of statistical significance is also greater. This is 
important to increase the validity of the differences under study so that the resulting calculations are more reliable.

This meta-analysis study was conducted to analyze trends in the relationship between employment status and maternal education level as well as cadre support with maternal visits to posyandu. The statistical power that is greater than the results of the meta-analysis can provide an overview and extrapolation to a larger population so that the conclusions obtained can be used as a basis for adopting a public health policy, especially in the revitalization of posyandu services in Indonesia.

\section{METHOD}

This type of research is a systematic literature review or a quantitative synthesis with a study design meta analysis. Meta analysis is a statistical technique to combine the results of two or more similar studies in order to obtain a quantitative combination of data. Meta analysis is intended to re-analyze research results that are processed statistically based on primary data.

Quality meta-analysis is largely dependent on the quality of the studies or the combined literature. Through the PRISMA procedure, the research sample is published articles related to factors related to the visit of mothers under five to posyandu, through the Google Scholar database and Garuda Portal for the duration of 2015-2020 at least the level of love 4. The inclusion criterion is a cross-sectional design that has results. $p$ value and Prevalence Ratio (PR). Three variables (mother's employment status, mother's education level, cadre support) as independent variables and posyandu visits as the dependent variable.

The search was carried out by entering the following keywords: education, occupation, cadres, posyandu and posyandu visits. Articles that have titles and abstracts that are potentially relevant are reviewed in full (full text) later, while articles that are not relevant are excluded. Furthermore, articles selected based on full text reviews are included in a systematic review and are further reviewed for clarity of factor definitions, data completeness, results and other matters as conditions for inclusion in the meta analysis.

Data were analyzed using RevMan 5.3 software. Data analysis was performed to obtain the value of the pooled odds ratio (pOR), which is the combined odds ratio value from research journals using a fixed effect model and a random effect model. The heterogeneity test was carried out in order to determine the incorporation model in the meta-analysis. The I2 statistical test was performed to assess the heterogeneity among a number of study effect sizes expressed in percentage terms. The final result of the meta-analysis is a forest plot with a pooled odds ratio and an effect size in each study. The funnel plot results were also analyzed for publication bias assessment of the final meta-analysis. The final value used as an answer to the research objectives is the value of the pooled odds ratio which shows the combined OR value of several studies. This shows how much the tendency of the relationship of each of the variables studied.

\section{RESULTS}

There are 7 studies that are included in the meta-analysis where in one research journal there are two or even three of the independent variables studied, 5 studies each for the variable mother's employment status, 4 studies for the variable level of maternal education and 3 studies for support cadres variable.

Table 1. Relationship between Work Status and Maternal Visits to Posyandu

\begin{tabular}{lllllll}
\hline \hline No. & Researcher & $\begin{array}{l}\text { Publication } \\
\text { year }\end{array}$ & N (sample) & P-value & OR & 95\% CI \\
\hline \hline $\mathbf{1}$ & Idaningsih A. & 2016 & 110 & 0.040 & 2,295 & $1,121-6,009$ \\
\hline $\mathbf{2}$ & Utami RB. et al. & 2016 & 101 & 0.180 & 1,181 & $0.590-5,570$ \\
\hline $\mathbf{3}$ & Gumayesty Y. & 2107 & 63 & 0.016 & 4,154 & $1,422-12,134$ \\
\hline $\mathbf{4}$ & Nurdin et al. & 2019 & 85 & 0.023 & 3,182 & $1,270-7,557$ \\
\hline $\mathbf{5}$ & Isnoviana M. et al. & 2020 & 91 & 0,000 & 0.465 & $0.260-0.580$ \\
\hline
\end{tabular}

Table 2. Relationship between Education Level and Maternal Visit to Posyandu

\begin{tabular}{lllllll}
\hline \hline No. & Researcher & $\begin{array}{l}\text { Publication } \\
\text { year }\end{array}$ & N (sample) & P-value & OR & 95\% CI \\
\hline \hline $\mathbf{1}$ & Idaningsih A. & 2016 & 110 & 0,000 & 6,800 & $2,812-16,442$ \\
\hline $\mathbf{2}$ & Utami RB. et al. & 2016 & 101 & 0.174 & 1.91 & $0.74-4.90$ \\
\hline $\mathbf{3}$ & Reihana et al. & 2016 & 407 & 0.001 & 0.340 & $0.185-0.625$ \\
\hline $\mathbf{4}$ & Gumayesty Y. & 2107 & 63 & 0.042 & 3,333 & $1,169-9,505$ \\
\hline
\end{tabular}

Table 3. Relationship between Cadre Support and Maternal Toddler Visits to Posyandu

\begin{tabular}{lllllll}
\hline \hline No. & Researcher & $\begin{array}{l}\text { Publication } \\
\text { year }\end{array}$ & N (sample) & P-value & OR & 95\% CI \\
\hline \hline $\mathbf{1}$ & Djamil A. & 2017 & 198 & 0.010 & 3,453 & $1,412-8,356$ \\
\hline $\mathbf{2}$ & Gumayesty Y. & 2017 & 63 & 0.004 & 6,028 & $1,271-10,668$ \\
\hline
\end{tabular}

This publication is licensed under Creative Commons Attribution CC BY.

http://dx.doi.org/10.29322/IJSRP.11.01.2021.p10981

WWW.ijsrp.org 
1. Mother's Work Status

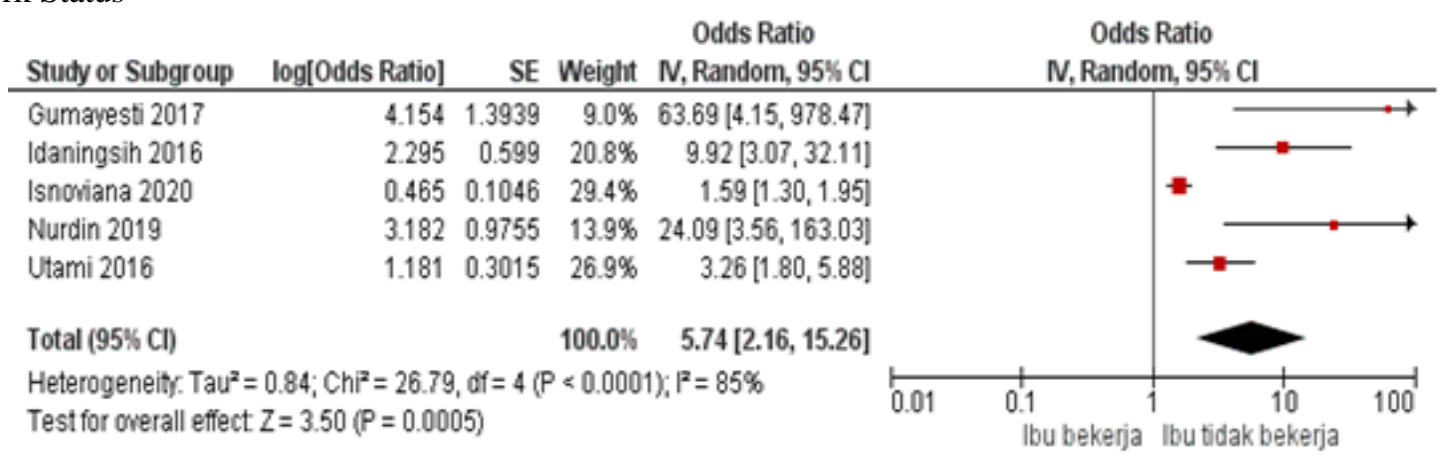

Figure 1. Forest plot of the relationship between employment status (working mothers) and visits to posyandu

a) The results of the high heterogeneity test (I2 $=85 \%$; $\mathrm{p}<0.0001)$ so that random effect models were used.

b) The statistical test results obtained $\mathrm{pOR}=5.74 ; 95 \% \mathrm{CI}=2.16$ to 15.26 ; $\mathrm{p}$ value $<0.0001$

c) Interpretation: Non-working mothers increased the risk or tended 5.74 times to visit mothers under five to posyandu compared to working mothers and it was statistically significant $(\mathrm{pOR}=5.74 ; 95 \% \mathrm{CI}=2.16$ to $15.26 ; \mathrm{p}$ value $=$ $0.001)$.

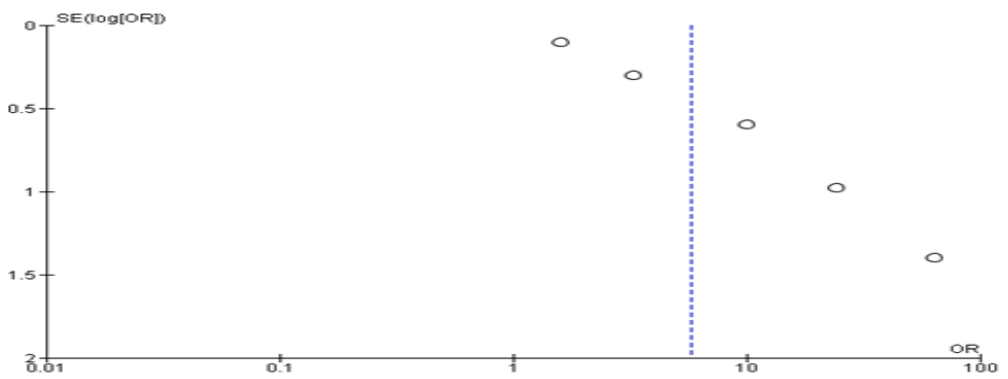

Figure 2.The funnel plot of the relationship between work status (working mother)

The results of the funnel plot show that there is a publication bias marked by the asymmetry of the plots on the right and left of the vertical line where the number of plots on the left is 2 and the right is 3 . The SE (Standard Error) values are 0.5 and 0 and the SE values are 1.5 and 0.5 on the right.

2. Mother's education level

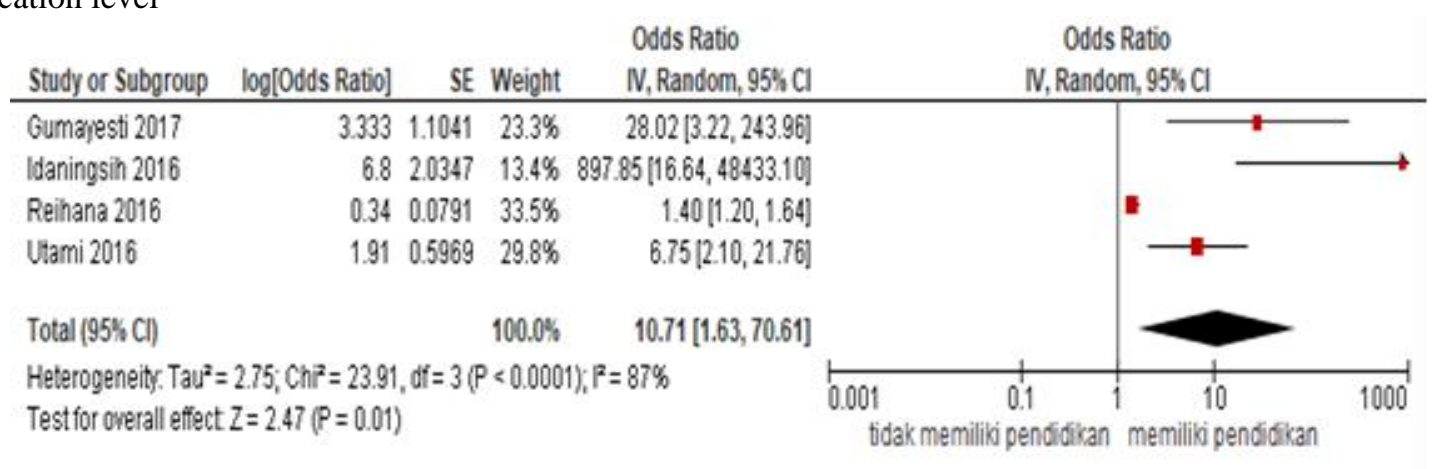

Figure 3. Forest plot of the relationship between maternal education level and visits to posyandu

a) The results of the high heterogeneity test (I2 $=87 \%$; $p<0.001$ ) so that random effect models were used.

b) The results of statistical tests showed that the results of porosity $=10.71 ; 95 \% \mathrm{CI}=1.63$ to $70.61 ; \mathrm{p}$ value $=0.01$

c) Interpretation: Mothers who have a history of high-secondary education have an increased risk of 10.71 times for visiting mothers under five to posyandu compared to mothers who have a history of basic education and are statistically significant $(\mathrm{pOR}=10.71 ; 95 \% \mathrm{CI}=1.63$ to $70.61 ; \mathrm{p}$ value $=0.01)$. 


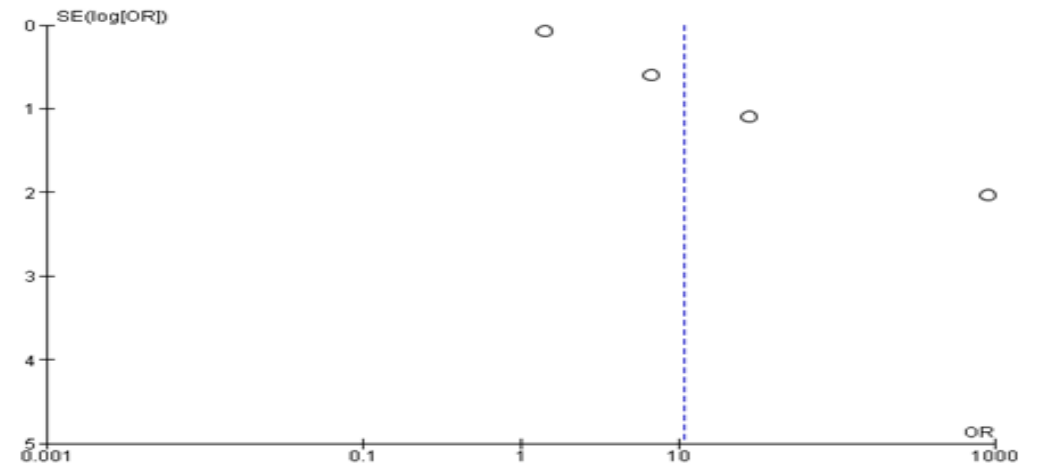

Figure 4. Funnel plot of the relationship between maternal education levels

The results of the funnel plot have a publication bias marked by the asymmetry of the plots on the right and left of the vertical line where the distance between the plots is not same. The SE (Standard Error) values on the left are 1 and 0 and the SE values on the right are 2 and 1.

3. Cadre Support

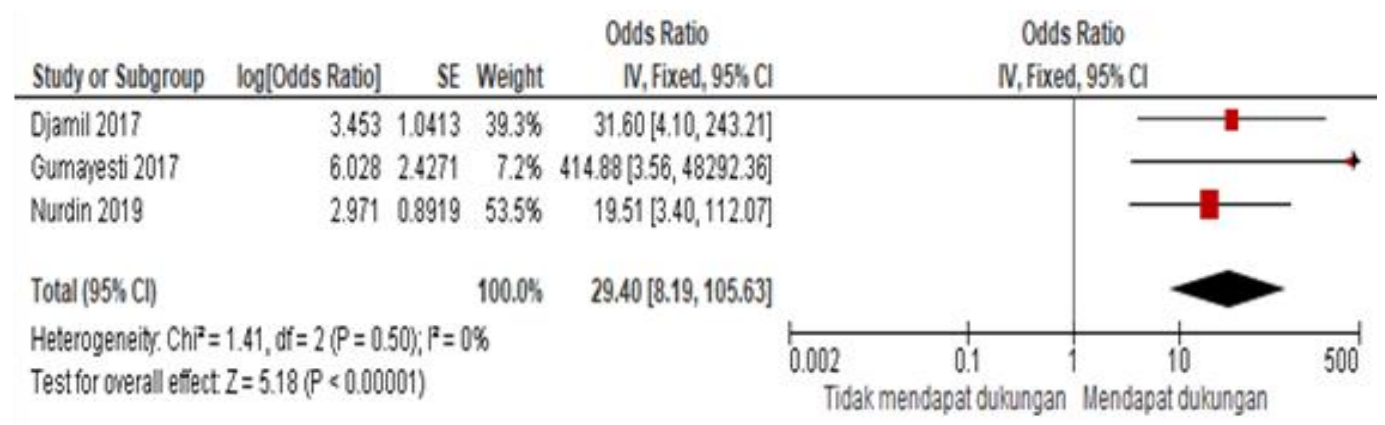

Figure 3. Forest plot of cadre support relationship with mothers of toddlers visit to posyandu

a) Low heterogeneity test results ( $\mathrm{I} 2=0 \%$; $<0.500)$ so that fixed effect models were used.

b) The result of statistical test shows that the value of $\mathrm{pOR}=29.40 ; 95 \% \mathrm{CI}=8.19$ to $105.63 ; \mathrm{p}$ value $<0.001$.

c) Interpretation of results: Mothers who received good support from cadres had an increased risk of 29.40 times for visiting mothers under five to posyandu compared to mothers who did not receive good support and were statistically significant $(\mathrm{pOR}=29.40 ; 95 \% \mathrm{CI}=8.19$ to $105.63 ; \mathrm{p}<0.001)$.

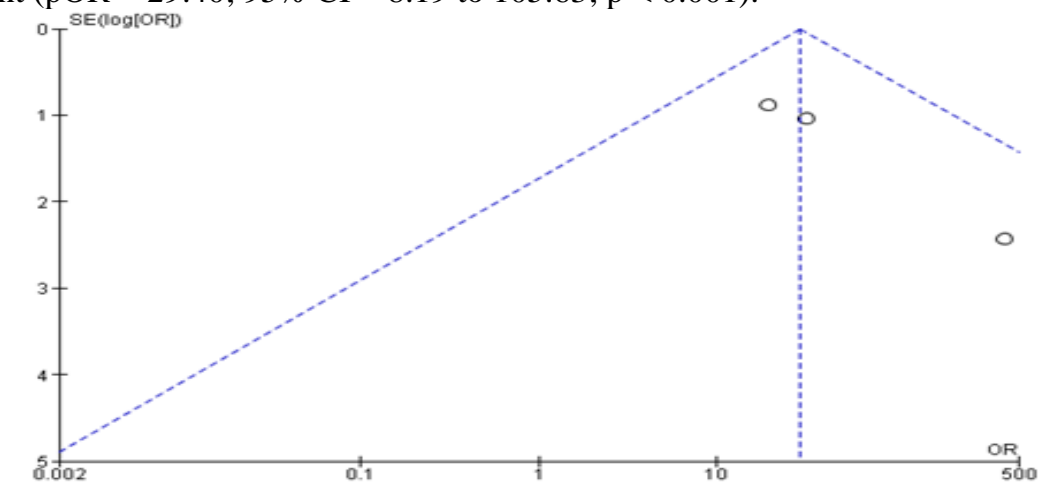

Figure 4.6. Funnel plot support cadre relationships

The results of the funnel plot show that there is a publication bias marked by asymmetrical plots on the right and left of the vertical line where the distance between the plots is not same. SE values (Standard Error) on the left 2 and 1 and SE values on the right 3 and 2 .

\section{DISCUSSION}

\section{Mother's Employment Status Relationship}

The results of the analysis of five studies showed different variance values and weights. Isnoviana (2020) This publication is licensed under Creative Commons Attribution CC BY. http://dx.doi.org/10.29322/IJSRP.11.01.2021.p10981 produces a weighted value of $29.4 \%$, which is the study with the largest weight while Gumayesty (2017) shows the lowest weight of $9.0 \%$. Comparing this with the theory expressed by Dahlan (2012) that the weight in a study is directly proportional 
to the number of research subjects (research sample). The high heterogeneity test results for these five studies were $\mathrm{I} 2=85 \%$ and $\mathrm{p}$ value $<0.000$, so using random effect models in measuring the combined effects in the RevMan 5.3 application. The results obtained were $\mathrm{pOR}=5.74$ with a $95 \%$ confidence interval: 2.16-15.26. The combined effect also produces a Zvalue of 3.50 and a p-value $=0.0005$. Statistically, the combined effect is significant if the $\mathrm{p}$ value $<0,05$ and the confidence interval does not touch the vertical line. This means that the null hypothesis is rejected, in other words there is a relationship between the work status of the mother and the mother's visit to the posyandu with the tendency of the mother not to work increasing the risk of 5.74 times to visit the posyandu compared to the working mother of the toddler.

The funnel plot shows the result of the SE value (Standard Error) to the left of 0.5 and 0 and the SE values to the right of 1.5 and 0.5 . There is an asymmetrical plot on the left and right of the vertical line and the number of plots is on the left 2 and the plot is on the right 3. This indicates a publication bias. Mohet et al., (2009) suggest a quantitative meta-analysis with a random effect model approach, although the combination of this information can produce a more precise statistical analysis, bias is unavoidable (Rumokoy LJM et al., 2020). This can occur in this study because of the inconsistency results of research studies that show high scores and varying data, which indicate a negative correlation and a positive correlation. The varied correlation results will show high heterogeneity (Waluyohadi AEG., 2019).

Work is one of the factors that influence behavior. The results of this meta-analysis are in accordance with the theory of Lawrence Green in Notoatmodjo (2012) who has developed a model approach used to make health planning known as the PRECEDE framework which stands for Predisposing, Reinforcing, and enabling cause in educational diagnosis and evaluation. In this framework, behavioral factors are influenced by several factors, namely predisposing factors, enabling factors and reinforcing factors (Notoadmodjo, 2014). Work that is included in predisposing factors is one of the important domains in shaping a person's behavior.

\section{The Relationship of Mother's Education Level}

The analysis of the four studies showed the results of different variance values and weights. Reihana's research (2016) produces a weight value of $33.5 \%$, which is the research with the largest weight among the four research studies, while Idaningsih's research (2016) shows the smallest weight at $13.4 \%$. The heterogeneity test results of these four studies were heterogeneous, seen from $\mathrm{I} 2=87 \%$ and $\mathrm{p}$ value $<0.0001$. These four studies have characteristics that are not the same as variations in the number of samples whose size does not match the population, so in the end they have an effect after the merger is carried out. The test results showed high heterogeneity so that random effect models were used. The results obtained were $\mathrm{pOR}=10.71$ with a $95 \%$ confidence interval: 1.63-70.61. The combined effect produces a $\mathrm{Z}$ value of 2.47 and a $\mathrm{p}$ value of 0.01 . Statistically, the combined effect is significant if the $\mathrm{p}$ value $<0.05$ and the confidence interval does not touch the vertical line. As seen in the funnel flot, the confidence interval value of the combined effect does not touch

This publication is licensed under Creative Commons Attribution CC BY.

http://dx.doi.org/10.29322/IJSRP.11.01.2021.p10981 the vertical line. This means that the null hypothesis is rejected, in other words there is a relationship between the level of maternal education and the visit of mothers under five to the posyandu with the tendency for mothers who have a history of high-secondary education levels tend to increase the risk.

The results of the funnel plot indicate that there is publication bias, marked by the asymmetry of the plots on the right and left of the vertical line where the distance between the plots is not same. The SE values (Standard Error) on the left 1 and 0 and the SE values on the right 2 and 1. Apart from the high degree of heterogeneity and inconsistency of the study results, it is necessary to consider other things that could cause publication bias. According to DeCoster (2009), one of the weaknesses in meta-analysis is publication bias. The publication bias that is meant in this meta-analysis uses data that has published research so that it is considered unrepresentative of research because significant observations are more likely to be published than insignificant ones (Waluyohadi AEG., 2019).

Education is one of the factors that influence behavior. The results of this meta-analysis are in accordance with the behavioral theory of factors related to the use of health service facilities according to Andersen RM (1968) in the Behavioral Model of Families Use of Health Services, the behavior of individuals using health services together is influenced by 3 factors, namely predisposing factors (demographic characteristics). , social structure which includes education, attitudes and beliefs), enabling factors (economic status, access or distance and responsibility), and need factors (factors for individual, family and disease needs) (Notoadmodjo, 2010).

Education is an effort to provide knowledge so that there is increased positive behavior change. The formal education level is the level of education that has been passed in either public or private educational institutions. The basic concept of education is a learning process which means that in education there is a process of growth, development or change for the better in individuals or groups of society. This concept explains an assumption that in order to achieve the values of life in society, humans as social beings in life always need the help of others who have advantages, are more mature, smarter, more capable and so on. In achieving these goals an individual or community group cannot be separated from learning activities (Notoadmojo, 2003 in Utami RB. Et al.,

\section{Cadre support relationship}

The analysis of the three studies showed the results of different variance values and weights. Djamil A.'s research (2017) produces a research weight of $39.3 \%$, then research by Gumayesty Y. (2017) has a weight of $7.2 \%$ which is the least weighted research and research by Nurdin et al., (2019) with weights the largest among the three research studies at $53.5 \%$. Heterogeneity test is carried out in determining the role of variation between studies objectively. The results of the heterogeneity test $\mathrm{I} 2=0 \%$ and the value of $\mathrm{p}=0.50$ indicates p> 0.05 , it is declared homogeneous, meaning that the variation between studies does not contribute to the total variation. The null hypothesis is accepted if the $\mathrm{p}$ value in the heterogeneity test is greater than 0.05 (Dahlan, 2012). The variation of the three research studies had no effect on the total variation after 
the combined effect. These three studies have the same or nearly the same characteristics as the variation in the number of samples which is equal in size to the population and in the end there is no effect after the merger. Measurement of the combined effect of this homogeneous data using a fixed effect model obtained is pOR $=29.40$ with a $95 \%$ confidence interval: 8.19-105.63. The combined effect resulted in a $\mathrm{Z}$ value of 5.18 and a $\mathrm{p}$ value $<0.001$. In statistical assessments, the combined effect was significant if the $p$ value $<0.001$ and the confidence interval did not touch the vertical line. As seen in the funnel flot, the confidence interval value of the combined effect does not touch the vertical line. This means that the null hypothesis is rejected, in other words there is a relationship between the support of cadres and the visit of mothers under five to posyandu with the tendency for mothers who get good support from cadres to increase the risk 29.40 times to visit mothers under five to the posyandu compared to mothers who do not. get good support from posyandu cadres.

In the funnel plot, it shows that there is a publication bias marked by the asymmetry of the plot on the right and left of the vertical line where the distance between the plots is not same. The SE values (Standard Error) on the left 2 and 1 and the SE values on the right 3 and 2.In this context, the level of heterogeneity of the data obtained is actually very low (homogeneous) but publication bias can occur because the weight / weight between studies is too far the difference, it appears that the research of Nurdin et al. with the highest weight of $53.5 \%$ and the lowest of $7.2 \%$ (Gumayesty Y.) so that they have too far a range of differences.

The active role and support of cadres is one of the factors that influence individual behavior in using health services. The results of this meta-analysis study reinforce the findings of previous studies and are in accordance with the theory put forward by Snehandu B. Kar (1983) who tries to analyze health behavior by pointing out that the behavior is a function of five aspects, namely a person's intention to act (behavior intention)., social support from the surrounding community (social support) including the role of community leaders and cadres, information about health or health facilities (accesbility of information), making actions or decisions (personal anatomy) and situations that allow for action (action situation) (Muliati NM et al., 2020).

Cadres are members of the local community who are selected and reviewed by the community and can work voluntarily in managing Posyandu. Cadres are the main pillar of development, especially in the health sector, they are independently involved by the Puskesmas in activities in health services in the village, without cadres, health service activities in the village do not mean much (Farida, 2013 in Gumayesty Y., 2017).

Support from outside the individual is also an important domain in shaping one's behavior. Although cadre support does not stand alone, where there are many types of support received by mothers of toddlers, cadre support is one of the factors that need to be considered to improve performance and their active role in directing and supporting the behavior of mothers under five in using health service facilities, in this case the use of posyandu .

\section{CONCLUSION}

1. The variable of maternal employment status was analyzed by 5 research articles that match the inclusion criteria. The results of the interpretation obtained were mothers who did not work increased the risk or tended to be 5.74 times more likely to visit mothers under five to posyandu compared to working mothers and it was statistically significant $(\mathrm{POR}=$ $5.74 ; 95 \% \mathrm{CI}=2.16$ to 15,26 ; $\mathrm{p}$ value $=0.001$ ) .

2. The variable of mother's education level was analyzed by 4 research articles that match the inclusion criteria. The results of the interpretation obtained are mothers who have a history of high-secondary education levels increase the risk or have a tendency of 10.71 times to visit mothers under five to posyandu compared to mothers who have a history of primary education level and are statistically significant $(\mathrm{POR}=10.71 ; 95 \% \mathrm{CI}=1.63$ to $70.61 ; \mathrm{p}$ value $=0.01$ ).

3. Cadre support variables were analyzed by 3 research articles which stated that there was a significant relationship between cadre support and maternal visits to posyandu. The result of the interpretation obtained was that mothers who received good support from cadres increased the risk or had 29.40 tendencies to make visits to mothers under five to the posyandu compared to mothers who did not get good support and were statistically significant $(\mathrm{POR}=29.40 ;$ CI $95 \%=8.19$ to $105.63 ; \mathrm{p}<0.001)$.

4. The effect size used was the pooled odds ratio where the combined effect showed a $p$ value $<0.05$, which means that the three independent variables had a relationship with the mother's visit to the posyandu with different significance.

5. The results of this research synthesis prove the truth of several theories about health behavior, including the RM theory. Andersen, B. Kar's theory and L. Green's theory that health behavior is influenced by many factors, both internal and external. The variables of maternal employment status, mother's education level and cadre support have a relationship with the participation and visits of mothers under five in the use of posyandu services without neglecting other factors.

\section{SUGGESTION}

1. Further research is needed on the factors associated with the participation or visits of mothers under five to posyandu, especially those that provide different analysis results.

2. It is hoped that further meta-analysis research will further enrich references and increase the number reviewed so as to minimize publication bias that occurs in the study.

3. The application of meta-analysis is a quantitative analysis method that can be used in carrying out a scientific search to prove the quality of each study so that new quantitative data can be obtained and more accurate conclusions can be drawn. The conditions of the Covid-19 pandemic limit the physical space to carry out experiments, so this method is very suitable to be used as a tool for carrying out scientific exploration in current conditions.

\section{REFERENCES}


Dahlan, M.S. (2012) Pengantar Meta-Analisis disertai aplikasi meta-analisis dengan menggunakan program excel seri $12 C D$. Penerbit: Epidemiologi Indonesia (pstat consulting). Jakarta.

Djamil, A. (2017) Faktor-faktor yang berhubungan dengan Perilaku Ibu Balita Menimbang Anaknya ke Posyandu. Jurnal Kesehatan Volume VIII, Nomor 1; 127-134.

Gumayesty, Y. (2017) Determinan Kunjungan Anak Bawah Lima Tahun ke Posyandu di Kelurahan Pusaran Kecamatan Enok Kabupaten Indragiri Hilir. Jurnal Kesehatan Komunitas Volume 3 Nomor 4; 138-144

Hunter, J. E., Jensen, J. L., Rodgers, R. (2014) The Control Group and Meta-Analysis. Journal of Methods and Measurement in the Social Science Volume 5(1); 3-21.

Idaningsih, A. (2016) Faktor-faktor yang berhubungan dengan Kunjungan Balita ke Posyandu. Jurnal Ilmiah Indonesia Vol. 1 No. 2; 16-29.

Isnoviana M., Yudit J. (2020) Hubungan Status Pekerjaan dengan Keaktifan Kunjungan Ibu dalam Posyandu di Posyandu X Surabaya. Jurnal Ilmiah Kedokteran Wijaya Kusuma Vol 9 No 2; 112-122.

Kementerian Kesehatan Republik Indonesia. (2018) Riset Kesehatan Dasar 2018. Penerbit: Balai Penelitian dan Pengembangan Kesehatan Kemenkes RI. Jakarta.

Muliati N.M., Sudirman, Yusuf H. (2020) Faktor-faktor yang Berhubugan dengan Minat Remaja Berkunjung ke Posyandu di Kelurahan Baiya Kecamatan Tawaeli. Jurnal Kolaboratif Sains Volume 1 Nomor 1; 179195.

Notoatmodjo, S. (2010) Ilmu Perilaku Kesehatan. Penerbit: PT Rineka Cipta. Jakarta.

Nurdin, Ediana. D, Ningsih. N.D. (2018) Faktor-Faktor yang Berhubungan dengan Partisipasi Ibu Balita ke Posyandu di Jorong Tarantang. Jurnal Endurance: Kajian Ilmiah Problema Kesehatan Vol. 4 No. 1; 220234.

Reihana, Duarsa, A.B.D. (2016) Faktor-faktor yang berhubungan dengan Tingkat Partisipasi Ibu Balita untuk Menimbang Balita ke Posyandu di Wilayah Kerja Puskesmas Panjang Bandar Lampung tahun 2010. Jurnal Kebijakan Kesehatan Indonesia Vol. 05 No. 2; 67-72.

Laurentius J.M. Rumokoy L.J.M., Salaki C.L., Memah V.V., Sri Adiani S., Toar W.L. (2020) Penerapan MetaAnalisis dalam Eksplorasi Peranan Serangga terhadap Performa Pertumbuhan Ternak Entomopagus di Era Normal Baru Pasca Pandemi Covid-19. Prosiding Seminar Teknologi dan Agribisnis Peternakan VIIWebinar. Fakultas Peternakan Universitas Jenderal Soedirman. Purwokerto

Sastroasmoro, S. (2011) Dasar-dasar Metodologi Penelitian Klinis. Sagung Seto. Jakarta

Utami. R. B., Damayanti. D.F. (2016) Faktor-faktor yang Berhubungan dengan Perilaku Ibu dalam Melakukan Kunjungan ke Posyandu. Jurnal Vokasi Kesehatan Volume II Nomor 1; 41-48 